\title{
Isolation and Characterization of Phyllospheric Methylotrophic Bacteria of Paddy from Middle Gujarat, India
}

\author{
Ronak R. Prajapati*, R.V. Vyas and Y.K. Jhala \\ Department of Agricultural Microbiology and Biofertilizers Project, B. A. Collage of \\ Agriculture, Anand Agricultural University, Anand-388110, Gujarat, India \\ *Corresponding author
}

\section{A B S T R A C T}

\section{Keywords}

Phyllosphere, Methylotrophs, Soluble methane monooxygenase, Methanol dehydrogenate, Paddy

Article Info

\section{Accepted:}

19 April 2017 Available Online: 10 May 2017
Phyllospheric methylotrophic bacteria were isolated from leaf surface of paddy from Anand, Thasra and Nawagam Tehshil on NMS medium supplemented with methanol $(1 \%)$ by Leaf imprinting technique. Among 33 isolates three potent isolates viz. M 3, M 10 and M 15 showed fourfold increase in cell numbers in methanol $1 \%$ solution. Isolate M 3, M 10 and M 15 were found Gram +ve, rods occurring singly. Isolate M 3, M 10 and M 15 showed yellow, dull white and shiny white pigmented growth respectively, on NMS media. From cultural and microscopic characteristics it was accepted that, isolates belongs to family Bacillaceae. Isolate M 15 were found tolerating higher $\mathrm{pH}$ range (9.0) and 7.5\% $\mathrm{NaCl}$ concentration as compared to other isolates Isolate M 10 and M 15 showed resistant to wide range of antibiotics and were found to utilize carbon sources. On the basis of partial 16S rRNA gene sequencing selected phyllospheric isolates, AAU M 3 was identified as Staphylococcus saprophyticus, AAU M 10 as Bacillus subtilis, AAU M 15 as Bacillus methylotrophicus. Chosen three isolates were subjected to qualitative detection of two key enzymes of bacterial methane degradation pathway viz. soluble methane monooxygenase (sMMO) and methanol dehydrogenase (MDH) and established positive.

\section{Introduction}

A family of symbiotic bacteria belonging to the genus Methylobacterium known as "pinkpigmented facultative methylotrophic bacteria" (PPFMs) plant's best friend. They are ubiquitous in nature and have been detected in soil, dust, freshwater, lake sediments, on leaf surfaces and nodules, in rice grains, air, as well as on other solid surfaces. They are aerobic, Gram-negative bacteria and although they are able to grow on a wide range of multi-carbon substrates, they are characterized by the capability to grow on one carbon compounds such as formate, formaldehyde or methanol as the sole carbon and energy source and thus easily be isolated on a methanol-based mineral medium.

These methylotrophic bacteria are known to metabolize methanol but also few limited $\mathrm{C} 1$ carbon substrates, as well as organic acids and alcohols. Plant surfaces release diverse carbon sources, mainly sugars and organic acids in 
low amounts $(\mu \mathrm{M})$ and these sources are heterogeneously located resulting of leaching through the cuticle. In addition to these substrates, volatile carbon substrates, particularly the plant cell wall metabolism byproduct methanol are released via the stomata. Methanol emission peaks in the morning, when the stomata first open.

There is evidence that methanol is consumed by Methylobacterium and contributes to the epiphytic fitness of the organism. However, in addition to the peak of methanol emission in the morning, Methylobacterium should adapt its metabolism to use additional carbon sources during the rest of the day when methanol emission is low or during the night when stomata are closed. These PPFMs are especially abundant in Rhizosphere but also found on leaves of field-grown crops averaged about $106 \mathrm{cfu}$ of PPFMs per leaflet and typically $>80 \%$ of the viable bacteria recovered from leaves were PPFMs (Omer et al., 2004).

\section{Materials and Methods}

\section{Isolation of phyllospheric methylotrophic bacteria}

Seven leaf samples were collected from wetland paddy fields of Agricultural Research Station for Irrigated Crops, Thasra as well as from farmer's fields of Thasra Taluka growing paddy customarily by Leaf imprinting technique on selective medium Nitrate mineral salt (NMS) (Sodium nitrate $2.0 \mathrm{~g} \mathrm{l}^{-1}, \mathrm{MgSO}_{4} 7 \mathrm{H}_{2} \mathrm{O}-0.2 \mathrm{~g} / \mathrm{l}, \mathrm{KCl}-0.04 \mathrm{~g} \mathrm{l}^{-1}$, Calcium chloride-0.015 g l-1, $\mathrm{Na}_{2} \mathrm{HPO}_{4}-0.21$ $\mathrm{g} \mathrm{l}^{-1}, \mathrm{NaH}_{2} \mathrm{PO}_{4}-0.09 \mathrm{~g} \mathrm{l}^{-1}, \mathrm{FeSO}_{4} 7 \mathrm{H}_{2} \mathrm{O}-0.01$ $\mathrm{mg} \mathrm{l}^{-1}, \mathrm{CuSO}_{4} 5 \mathrm{H}_{2} \mathrm{O}-5 \mathrm{mg} \mathrm{l}^{-1}, \mathrm{H}_{3} \mathrm{BO}_{4}-10$ mg 1-1, MnSO4 $5 \mathrm{H}_{2} \mathrm{O}-10 \mathrm{mg} \mathrm{l}^{-1}, \mathrm{ZnSO}_{4}$ $7 \mathrm{H}_{2} \mathrm{O}-70 \quad \mathrm{mg} \quad \mathrm{l}^{-1}, \quad \mathrm{MoO}_{3} \quad-\quad 10 \mathrm{~g} \quad \mathrm{l}^{-1}$ ) supplemented with filter-sterilized cyclohexamide $(10 \mathrm{mg} / \mathrm{ml})$ and $1 \%$ methanol (v/v) at $28^{\circ} \mathrm{C}$ (Corpe, 1985).
In vitro screening of methylotrophic activity

The isolates were tested for utilization of methane gas @ 1\% and methanol @ 1 to 5\% as sole source of carbon in evacuated tubes containing water + methane or methanol separately to confirm methylotrophic metabolism (Jhala et al., 2015). Growth and survival of isolates were measured by recording colony counts from the tubes at 10 days after inoculation on NMS media.

\section{Characterization of the potential methylotrophic isolates}

Methanol or methane utilizing bacteria (primary screened) were characterized on the basis of morphological, Biochemical and molecular characteristics using Bergey's Manual of Systematic Bacteriology (Bergey's, 1939).

\section{Morphological characterization}

Morphological characteristics of methylotrophic isolates were recorded by two means after obtaining pure cultures on NMS agar medium: Cultural characteristics of organisms viz. size, shape, elevation, margin, elevation, texture, opacity and pigmentation were recorded and microscopic characteristics viz. size, shape, arrangement, motility and Gram's reaction were recorded. The $\mathrm{pH}$ tolerance of all isolates was tested on the nutrient broth medium adjusted to $\mathrm{pH}$ 5.0, 7.0 and 9.0 and salt tolerance of isolates were tested for salt $(\mathrm{NaCl})$ tolerance in NMS broth with $1 \%$ methanol having 2.5, 5.0 and $7.5 \%$ of $\mathrm{NaCl}$ concentration. The bacterial suspension $\left(0.1 \mathrm{ml}\right.$ having $\left.10^{7} \mathrm{CFU} / \mathrm{ml}\right)$ of methylotrophic isolates was inoculated into broth in tubes. The inoculated isolates were incubated at $28^{\circ} \mathrm{C}$ for $1-3$ days. The presence or absence of growth was recorded by spectrophotometer (OD @ 600nm). Potential 
isolates were grown in Nutrient broth at $30+2^{\circ} \mathrm{C}$ for $24 \mathrm{~h}$ and $0.1 \mathrm{ml}$ of each culture was spreaded on nutrient agar plates. The discs of antibiotics (HiMedia make) were kept on inoculated plates at equidistance from each other. Plates were incubated at $28^{\circ} \mathrm{C}$ for $48 \mathrm{~h}$. Zone of inhibition was observed for each antibiotic disc and diameter from two sides was recorded (Jhala et al., 2015).

\section{Biochemical characterization}

Biochemical tests readymade kits available from HiMedia (HiPure Bacterial Identification Kit) were used. Individual bacterial suspension (50 $\mu \mathrm{l} @ 107 \mathrm{CFU} / \mathrm{ml})$ was inoculated in each well of test strips and allowed to incubate for $24 \mathrm{~h}$ at $28^{\circ} \mathrm{C}$. After incubation, observations were recorded by applying appropriate reagents provided with the kit.

\section{Utilization of other $\mathrm{C} 1$ compounds}

Isolates were tested for utilization of formaldehyde, methylacetate and trichloroethylene @ 1 to $5 \%$ as sole source of carbon in evacuated tubes to confirm methylotrophic metabolism. The growth and survival of isolates was measured by recording growth of microorganisms at 10 days after inoculation.

\section{Molecular characterization}

\section{S rRNA gene amplification}

Genomic DNA of all phyllospheric methylotrophic bacterial isolates were isolated using the protocol described by Sambrook et al., (1989). The amplification of the 16S rRNA gene by PCR was performed in PCR reaction mixture $(25 \mu \mathrm{l})$ containing 2.5 $\mu l$ Taq Buffer $(10 \mathrm{X}), 0.5 \mu \mathrm{l}$ dNTPs $(2.5 \mathrm{mM}$ each) mix, $2.0 \mu \mathrm{l}$ Template DNA $(25 \mathrm{ng} / \mu \mathrm{l})$, $0.2 \mu \mathrm{l}$ Taq polymerase $(5 \mathrm{U} / \mu \mathrm{l}), 17.8 \mu \mathrm{l}$ Millipore Sterilized Water using the following primer $1.0 \mu \mathrm{l}$ Primer 1 (27 F-5' - AGA GTT TGA TCC TGG CTC AG-3') and $1.0 \mu \mathrm{l}$ Primer 2 (1492 R- 5'-GGT TAC CTT GTT ACG ACT T-3') and the primers synthesized at MWG Bio-tech Pvt. Ltd., Germany. These primers designed on the basis of conserved sequences of eubacteria (Weisburg et al., 1991), were located at the extreme 50 and 30 of the $16 \mathrm{~S}$ rRNA gene, respectively, allowing an approximately 1500 -bp DNA fragment to be amplified. After mixing of all the components polymerize chain reaction was carried out in Mastercycler Personal (Eppendorf, Germany) with initial denaturation step at $94 \mathrm{C}$ for $5 \mathrm{~min}$ followed by 35 cycles of denaturation ( $94 \mathrm{C}$ for $1 \mathrm{~min}$ ), annealing (58 $\mathrm{C}$ for $1 \mathrm{~min}$ ) and extension (72 $\mathrm{C}$ for $2 \mathrm{~min}$ ) and final extension step at $72 \mathrm{C}$ for $10 \mathrm{~min}$. PCR amplified products were run on agarose gel electrophoresis.

\section{DNA sequencing analysis}

After PCR amplification, purification of amplicons was done by quick-spin PCR purification kit (Mo-Bio Laboratories) following user's instruction manual. The column was used to remove primers and other reagents from the PCR product. Quantification of the PCR purified fragments was carried out by Nano-Drop Spectrophotometer, measuring OD at 230, 260 and $280 \mathrm{~nm}$. Concentration of $15 \mathrm{ng} / 100$ bp was made as required for DNA sequencing of these PCR purified amplicons. Partial 16S rRNA gene sequencing was carried out for promising isolates and was performed using the ABI PRISM ${ }^{\circledR}$ BigDye $^{\mathrm{TM}}$ Terminator cycle sequencing kit on the ABI PRISM 3100 genetic analyser (Chromous biotech). The $16 \mathrm{~S}$ rRNA gene sequences were assembled using MEGA 4 software, compared with other strains using NCBI BLAST analysis for identification purpose and comparison of homologies of isolated strains with previously characterized. 
In vitro enzyme activities for methane degradation

Activities of two key enzymes (methane monooxygenase and methanol dehydrogenase) involved in methane oxidation were studied. For qualitative detection of sMMO enzyme, isolates were grown on NMS media with and without $\mathrm{CuSO} 4$ and incubated for $72 \mathrm{~h}$ at $28^{\circ} \mathrm{C}$. After incubation, few naphthalene crystals were sprinkled in the lid of the plate and the plates were stored in inverted position at $28^{\circ} \mathrm{C}$ for 15 min in air followed by gentle spray of freshly prepared, ortho-dianisidine dye $(5 \mathrm{mg} \mathrm{ml}-1)$ for $2-3 \mathrm{sec}$. The lids were replaced and the plates were stored for $15 \mathrm{~min}$ in the presence of the dye. If naphthol was produced by the colonies, a purple-red colour appeared upon contact with the dye. The colour once formed, remained stable for at least $24 \mathrm{~h}$ at room temperature (Graham et al., 1992).

Qualitative detection of methanol dehydrogenase (MDH) was carried out following method of Eggeling and Sahm (1980) with some modifications.

\section{Results and Discussion}

\section{Isolation of phyllospheric methylotrophic bacteria from paddy}

Total 33 cultures were recovered from leaves of wet land paddy fields by leaf imprinting technique (Corpe, 1985). Only PPFMs were found predominating on the selective media Nitrate mineral salts (NMS) medium with methanol, bacterial colonies were appeared on media outlining the features of the leaf print (Plate.1).

Total 33 isolates were isolated from phyllosphere of paddy crop grown at different locations of middle Gujarat agro climatic zone III. Out of 33 isolates, 7 isolates designated as M 1 to M 7 of Agricultural Research Station for Irrigated Crops, Thasra of which M 1 and M 2 gave pink colour colony, isolate M 3 to M 6 gave yellow colour colonies and isolate M 7 exhibited white colour colony. One isolate M 8 was isolated from farmer's field Thasra showed pink colour colony. Three isolates M 9 to M 11 of Regional Research Station, AAU, Anand, isolate M 9 gave pink, isolate M 10 gave white and M 11 gave yellow colour colonies. Eight isolates, M 12 to M 19 of Crop Cafeteria, Department of Agronomy, AAU, Anand isolate M 12 and M 13 gave pink, isolate M 14 and M 15 gave white and isolate M 16, M 17, M 18 and M 19 gave yellow colour colonies. Three isolates M 20 to M 22 of farmer's field, Dist. Anand, amongst which isolate M 20 gave orange, isolate M 21and M 22 gave pink colour colonies. Four isolates M 23 to M 26 isolated from farmer's field, Bandhani, of which isolate M 23 and M 26 gave yellow, isolate M 24 gave pink and isolate M 25 gave white colour colonies.

Seven isolates M 27 to M 33 were of Main Rice Research Station, AAU, Nawagam of which isolate M 27 to M 30 exhibited pink, isolate M 31 and M 32 shoved yellow and isolate M 33 gave white colour colonies (Table 4.1) Kim et al., 2010 methylotrophic bacterial isolated using leaf prints technology on AMS medium and observed growth on outlining leaf print after week of inoculation at room temperature.

In vitro screening of phyllospheric bacterial isolates for utilization of methane gas and methanol

Among the 33 cultures, 19 isolates viz, M 3, M 10, M 11, M 12, M 13, M 14, M 15, M 16, M 18, M 21, M 22, M 23, M 25, M 26, M 27, M 28, M 29, M 32 and M 33 were found to multiply in $1 \%$ methane + water as well as 1 
$\%$ methanol + water. Among all the 33 isolates three potent isolates viz. M 3, M 10, and M 15 were chosen for study (Table.1, Plate.2). They were chosen due to better CFU.

Results pertaining to survival of phyllospheric methylotrophic bacterial isolates on methanol in the concentration range of 1 to $5 \%$ are presented in Table 4.3. Results showed that chosen three isolates were capable to survive and multiply on methanol concentration up to $5 \%$ level incorporated in NMS broth increase in cell numbers after 10 days of inoculation. Isolate $M$ 3, M 10 and $M 15$ were able to efficiently utilize methanol showing 3 fold increases in cell numbers from initial 102 to 107 at $10 \mathrm{DAI}$.

These results are supporting the fact that methylotrophs oxidize methane to methanol which is further oxidized to formaldehyde and utilized by organisms for growth by assimilation in cell carbon pool (Anthony, 1982). Arfman et al.,(1989) reported growth of Bacillus sp. On $\mathrm{C} 1$ compound methanol in batch culture at a high rate $(1,100-1,500 \mathrm{nmol}$ min-1, mg of protein-1). The short chain (C1 C4) primary alcohols were oxidized, but compared to methanol $(100 \%)$ at lower relative rates (ethanol, 90\%; n-propanol, 57\%, n-butanol, 53\%). Secondary alcohols and formate were not oxidized, while the organism oxidized various alcohols but grew well on methanol.

\section{Characterization of potential phyllospheric methylotroph isolates}

Three potential phyllospheric methylotrophic bacterial isolates were further subjected to morphological, biochemical, physiological and molecular characterization.

\section{Morphological characterization}

All the isolates showed variable growth patterns on NMS media as narrated in
Table.3. Isolate M 3, M 10 and M 15 showed yellow, dull white and shiny white pigment, respectively Plate.4. Isolate M 3, M 10 and M 15 were found Gram +ve, rods occurring singly (Table.4). From cultural and microscopic characters it was assumed that, isolate M 3, M 10 and M 15 may belongs to family Bacillaceae.

\section{Physiological characterization}

The results of $\mathrm{pH}$ tolerance of isolates are presented in Table.5. Chosen methylotrophic bacterial isolates have wide $\mathrm{pH}$ tolerance range like 5.0, 7.0 and 9.0. Maximum growth was obtained at $\mathrm{pH} 7.0$ (Table.5) of all selected isolates, while little 1 more at $\mathrm{pH} 5.0$ and increasing at $\mathrm{pH} 9.0$, isolate $\mathrm{M} 15$ showed higher growth (1.247 and 1.508) as compared to isolate M 3 (0.300 and 0.810) and isolate M 10 (0.313 and 0.404). This indicates that neutral (7.0) and alkaline $\mathrm{pH}$ (9.0) support more growth than acidic $\mathrm{pH}$ of 5.0 and hence $\mathrm{pH} 7.0$ was maintained in the following studies. Palanichamy et al., (2012) a PPFM bacterial isolates were morphologically and biochemically characterized and identified as a member of the genus Methylobacterium. The result indicates that neutral and alkaline $\mathrm{pH}$ (7.5) support good growth.

The results of salt $(\mathrm{NaCl})$ tolerance of the chosen isolates are presented in Table 4.7. Maximum growth of selected isolates was found in $2.5 \% \mathrm{NaCl}$ concentration, while increasing the concentration of $\mathrm{NaCl}(\%)$ the growth decreased. Isolate M 15 showed higher growth (1.42) at $2.5 \% \quad \mathrm{NaCl}$ concentration as compared to M 3 (0.98) and M 10 (0.68). The result indicates that isolate M 15 was found more tolerant as compared to $\mathrm{M} 3$ and $\mathrm{M} 10$ at $7.5 \% \mathrm{NaCl}$ concentration (Table.6). This might be due to the proline which acts as predominant compatible solute independent of constant higher osmolality. Similar types of results were obtained by Knief et al., (2010). 
Data pertaining the antibiotic resistance profiles of potent methylotrophic bacterial isolates shown in Table.7. Isolate $M 10$ showed resistant to Ampicillin $(10 \mu \mathrm{g} / \mathrm{disc})$, Carbenicillin (100 $\mu \mathrm{g} / \mathrm{disc})$, Polymyxin-B (300 $\mu \mathrm{g} /$ disc) and Rifampicin $(5 \mu \mathrm{g} /$ disc) while isolate M 15 showed resistant to Ampicillin (10 $\mu \mathrm{g} /$ disc), Carbenicillin (100 $\mu \mathrm{g} /$ disc $), \quad$ Rifampicin (5 $\mu \mathrm{g} /$ disc) and Vancomycin $(30 \mu \mathrm{g} / \mathrm{disc})$ as well as tolerant (intermediate) to Chloramphenicol (30 $\mu \mathrm{g} /$ disc $)$ and Gentamycin $(10 \mu \mathrm{g} /$ disc $)$.

Table.1 Chosen methylotrophic bacterial count on NMS agar after exposure

To $1 \%$ methane at $10 \mathrm{DAI}$

\begin{tabular}{|l|c|c|}
\hline \multirow{2}{*}{ Isolates } & \multicolumn{2}{|c|}{ Bacterial counts $(\mathbf{c f u} / \mathbf{m l})$} \\
\cline { 2 - 3 } & Initial & 10 DAI \\
\hline M 3 & $1.8 \times 10^{2}$ & $3.2 \times 10^{6}$ \\
\hline M 10 & $2.7 \times 10^{2}$ & $6.9 \times 10^{6}$ \\
\hline M 15 & $2.5 \times 10^{2}$ & $7.8 \times 10^{6}$ \\
\hline
\end{tabular}

Table.2 Chosen methylotrophic bacterial CFU after exposure To 1 to $\mathbf{5 \%}$ methanol solution at $10 \mathrm{DAI}$

\begin{tabular}{|c|c|c|c|c|c|c|}
\hline \multirow{2}{*}{ Isolates } & \multicolumn{6}{|c|}{ Chosen bacterial counts at 10 DAI (cfu/mI) } \\
\cline { 2 - 7 } & Initial & $\mathbf{1 \%}$ & $\mathbf{2} \%$ & $\mathbf{3 \%}$ & $\mathbf{4} \%$ & $\mathbf{5} \%$ \\
\hline M 3 & $5.4 \times 10^{2}$ & $4.5 \times 10^{7}$ & $5.8 \times 10^{7}$ & $5.4 \times 10^{7}$ & $5.8 \times 10^{7}$ & $4.7 \times 10^{7}$ \\
\hline M 10 & $3.1 \times 10^{2}$ & $5.2 \times 10^{7}$ & $5.9 \times 10^{7}$ & $6.4 \times 10^{7}$ & $6.1 \times 10^{7}$ & $5.8 \times 10^{7}$ \\
\hline M 15 & $4.3 \times 10^{2}$ & $6.9 \times 10^{7}$ & $7.1 \times 10^{7}$ & $7.8 \times 10^{7}$ & $8.3 \times 10^{7}$ & $6.9 \times 10^{7}$ \\
\hline
\end{tabular}

Table.3 Colony characteristics of phyllospheric isolates on NMS medium with $1 \%$ methanol

\begin{tabular}{|l|c|c|c|}
\hline \multirow{2}{*}{ Colony } & \multicolumn{3}{|c|}{ Native phyllospheric methylotrophic Isolates } \\
\cline { 2 - 4 } Characteristics & M 3 & M 10 & M 15 \\
\hline Shape & Round & Round & Round \\
\hline Margin & Undulate & Entire & Regular \\
\hline Elevation & Flat & Flat & Raised \\
\hline Texture & Rough & Smooth & Smooth \& sighing \\
\hline Opacity & Translucent & Opaque & Opaque \\
\hline Pigment & Yellow & Dull white & Shiny white \\
\hline
\end{tabular}


Table.4 Microscopic characteristics

\begin{tabular}{|l|c|c|c|}
\hline Isolates & Shape & Arrangement & Gram's Reaction \\
\hline M 3 & Rod & Single & G +ve \\
\hline M 10 & Rod & Single & G +ve \\
\hline M 15 & Rod & Single & G +ve \\
\hline
\end{tabular}

Table.5 $\mathrm{pH}$ tolerance of isolates

\begin{tabular}{|l|c|c|c|}
\hline \multirow{2}{*}{ Isolates } & \multicolumn{3}{|c|}{ Optical density (OD @ 600nm) at 24 hrs. } \\
\cline { 2 - 4 } & \multicolumn{3}{|c|}{ pH range } \\
\cline { 2 - 4 } & $\mathbf{5}$ & $\mathbf{7}$ & $\mathbf{9}$ \\
\hline Control & 0.0 & 0.0 & 0.0 \\
\hline M 3 & 0.30 & 0.88 & 0.81 \\
\hline M 10 & 0.31 & 0.66 & 0.40 \\
\hline M 15 & 1.25 & 1.78 & 1.51 \\
\hline
\end{tabular}

Table.6 Salt tolerance of isolates

\begin{tabular}{|l|c|c|c|}
\hline \multirow{2}{*}{ Isolates } & \multicolumn{3}{|c|}{ Optical density (OD @ 600nm) at 24 hrs. } \\
\cline { 2 - 4 } & \multicolumn{3}{|c|}{ NaCl concentration (\%) } \\
\cline { 2 - 4 } & $\mathbf{2 . 5} \%$ & $\mathbf{5 . 0} \%$ & $\mathbf{7 . 5} \%$ \\
\hline Control & 0.0 & 0.0 & 0.0 \\
\hline M 3 & 0.98 & 0.55 & 0.05 \\
\hline M 10 & 0.68 & 0.65 & 0.23 \\
\hline M 15 & 1.42 & 1.19 & 0.66 \\
\hline
\end{tabular}

Table.7 Antibiotic resistance profiles of isolates

\begin{tabular}{|c|c|c|c|c|c|c|c|c|c|c|c|}
\hline \multirow{2}{*}{ Isolates } & \multicolumn{11}{|c|}{ Antibiotic tested } \\
\hline & AMP & CB & C & GEN & $\mathbf{K}$ & PB & RIF & SPT & $\mathbf{S}$ & TE & VA \\
\hline M 3 & $\mathrm{~S}$ & $S$ & $\mathrm{~S}$ & $S$ & $S$ & $\mathrm{~S}$ & $\mathrm{~S}$ & $S$ & $\mathrm{~S}$ & $\mathrm{~S}$ & $\mathrm{~S}$ \\
\hline M 10 & $\mathrm{R}$ & $\mathrm{R}$ & $\mathrm{S}$ & $\mathrm{S}$ & $S$ & $\mathrm{R}$ & $\mathrm{R}$ & $S$ & $S$ & $S$ & $S$ \\
\hline M 15 & $\mathrm{R}$ & $\mathrm{R}$ & I & I & $\mathrm{S}$ & $\mathrm{S}$ & $\mathrm{R}$ & $\mathrm{S}$ & $\mathrm{S}$ & $\mathrm{S}$ & $\mathrm{R}$ \\
\hline
\end{tabular}


Table.8 Antibiotic Resistance zone interpretation

\begin{tabular}{|l|c|c|c|c|}
\hline \multirow{2}{*}{ Antibiotic } & $\begin{array}{c}\text { Concentration } \\
\text { (mcg/disc) }\end{array}$ & Sensitive & Intermediate & Resistant \\
\cline { 3 - 5 } & & $\begin{array}{c}\text { mm or } \\
\text { more }\end{array}$ & $\mathbf{m m}$ & mm or less \\
\hline AMP- Ampicillin & 10 & 17 & $14-16$ & 13 \\
\hline CB- Carbenicillin & 100 & 23 & $20-22$ & 19 \\
\hline C- Chloramphenicol & 30 & 18 & $13-17$ & 12 \\
\hline GEN- Gentamycin & 10 & 15 & $13-14$ & 12 \\
\hline K- Kanamycin & 30 & 18 & $14-17$ & 13 \\
\hline PB-Polymyxin-B & 300 & 13 & $11-12$ & 11 \\
\hline RIF- Rifampicin & 5 & 20 & $17-19$ & 16 \\
\hline SPT- Spectinomycin & 100 & 18 & $15-17$ & 14 \\
\hline S- Streptomycin & 10 & 15 & $12-14$ & 11 \\
\hline TE- Tetracycline & 30 & 15 & $12-14$ & 11 \\
\hline VA-Vancomycin & 30 & 17 & $15-16$ & 14 \\
\hline
\end{tabular}

* Antimicrobial susceptibility testing-zone size interpretative chart-HiMedia

Table.9 Tests for specific breakdown products of isolates

\begin{tabular}{|l|l|c|c|c|}
\hline $\begin{array}{c}\text { Sr. } \\
\text { No. }\end{array}$ & \multicolumn{1}{|c|}{ Isolate } & M 3 & M 10 & M 15 \\
\hline 1. & ONPG & + & - & - \\
\hline 2. & Lysine utilization & + & - & + \\
\hline 3. & Ornithine utilization & + & - & + \\
\hline 4. & Urease & - & - & + \\
\hline 5. & Phenyl alanine deamination & - & - & - \\
\hline 6. & Nitrate reductase & - & - & - \\
\hline 7. & H2S production & + & + & - \\
\hline 8. & Citrate utilization & + & + & - \\
\hline 9. & Voges proskauer's & - & - & - \\
\hline 10. & Methyl red & - & - & + \\
\hline 11. & Indole & + & + & + \\
\hline 12. & Malonate utilization & & & \\
\hline
\end{tabular}

Keys: +: positive test, -: Negative test 
Table.10 Carbon substrate utilization by isolates after 48 hours of inoculation

\begin{tabular}{|c|l|c|c|c|}
\hline S. No. & Carbon source & M 3 & M 10 & M 15 \\
\hline 1. & Esculine hydrolysis & + & + & + \\
\hline 2. & Arabinose & + & + & + \\
\hline 3. & Xylose & + & + & + \\
\hline 4. & Adonitol & - & - & + \\
\hline 5. & Rhamnose & - & + & + \\
\hline 6. & Cellobiose & + & - & + \\
\hline 7. & Melibiose & + & + & + \\
\hline 8. & Sachharose & - & + & + \\
\hline 9. & Raffinose & + & + & + \\
\hline 10. & Trehalose & + & + & + \\
\hline 11. & Glucose & - & - & + \\
\hline 12. & Lactose & + & + & + \\
\hline 13. & Oxidase & & & + \\
\hline
\end{tabular}

Keys: +: positive test, -: Negative test

Table.11 Evaluation of isolates for $\mathrm{C}_{1}$ compounds utilization

\begin{tabular}{|l|c|c|c|c|}
\hline \multirow{4}{*}{ Isolates } & Concentration (\%) & M 3 & M 10 & M 15 \\
\hline \multirow{4}{*}{ Formaldehyde } & $\mathbf{1}$ & + & + & + \\
\cline { 2 - 5 } & $\mathbf{2}$ & - & - & - \\
\cline { 2 - 5 } & $\mathbf{3}$ & - & - & - \\
\cline { 2 - 5 } & $\mathbf{4}$ & - & - & - \\
\hline \multirow{4}{*}{ Methyl acetate } & $\mathbf{5}$ & - & - & - \\
\cline { 2 - 5 } & $\mathbf{1}$ & - & - & + \\
\cline { 2 - 5 } & $\mathbf{2}$ & - & - & + \\
\cline { 2 - 5 } & $\mathbf{3}$ & - & - & - \\
\hline \multirow{4}{*}{\begin{tabular}{c} 
Trichloro \\
\cline { 2 - 5 }
\end{tabular}} & $\mathbf{4}$ & - & - & - \\
\cline { 2 - 5 } & $\mathbf{5}$ & - & - & - \\
\cline { 2 - 5 } & $\mathbf{1}$ & - & - & + \\
\cline { 2 - 5 } & $\mathbf{2}$ & - & - & - \\
\cline { 2 - 5 } & $\mathbf{3}$ & - & - & - \\
\hline
\end{tabular}




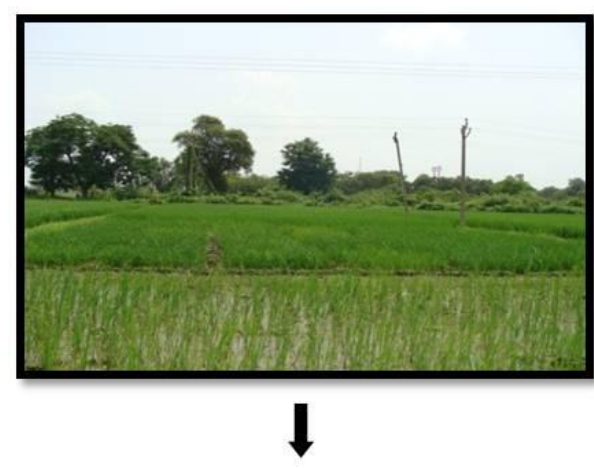

\section{Source of organism From farm}

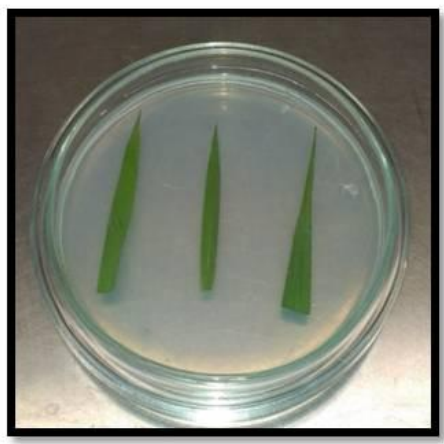

\section{Leaf surface imprints}

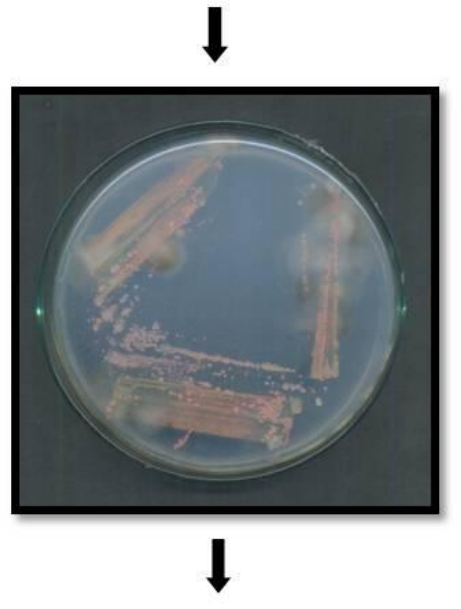

\section{PPFMs bacterial colonies appear}

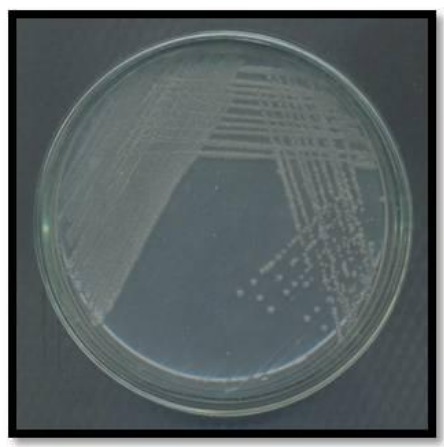

\section{Purification of bacterial colony}

Plate.1 Isolation of phyllospheric methylotrophic bacteria from rice leaf by leaf imprinting technique 

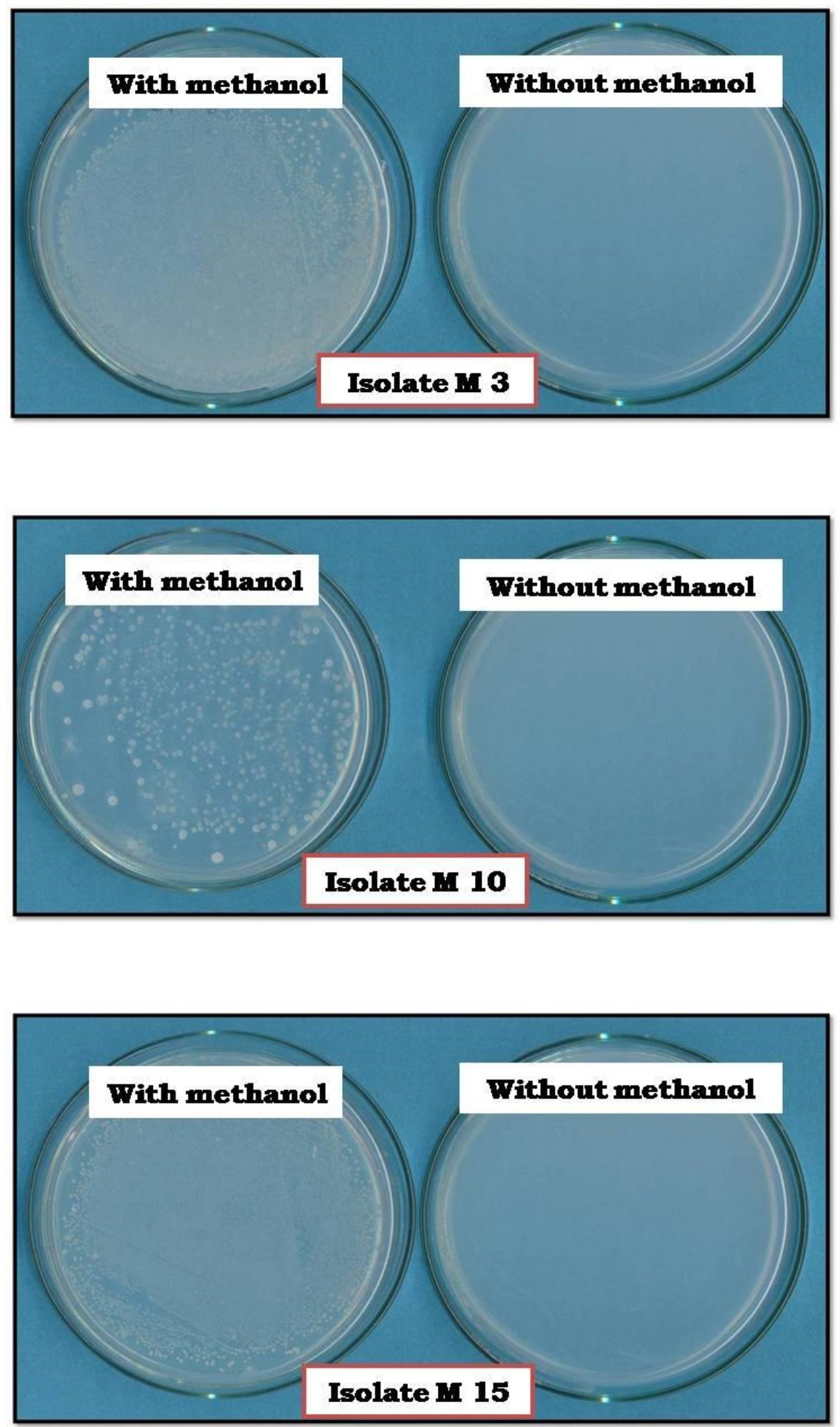

Plate.2 Methylotrophic bacterial growth on NMS agar after exposure to $1 \%$ methanol 

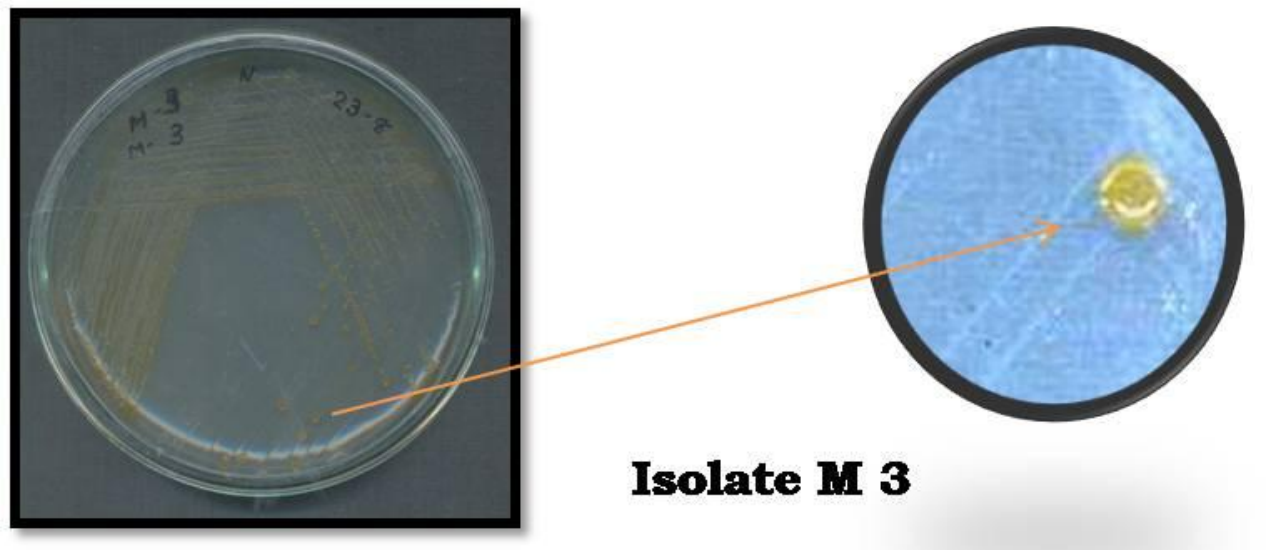

\section{Isolate M 3}
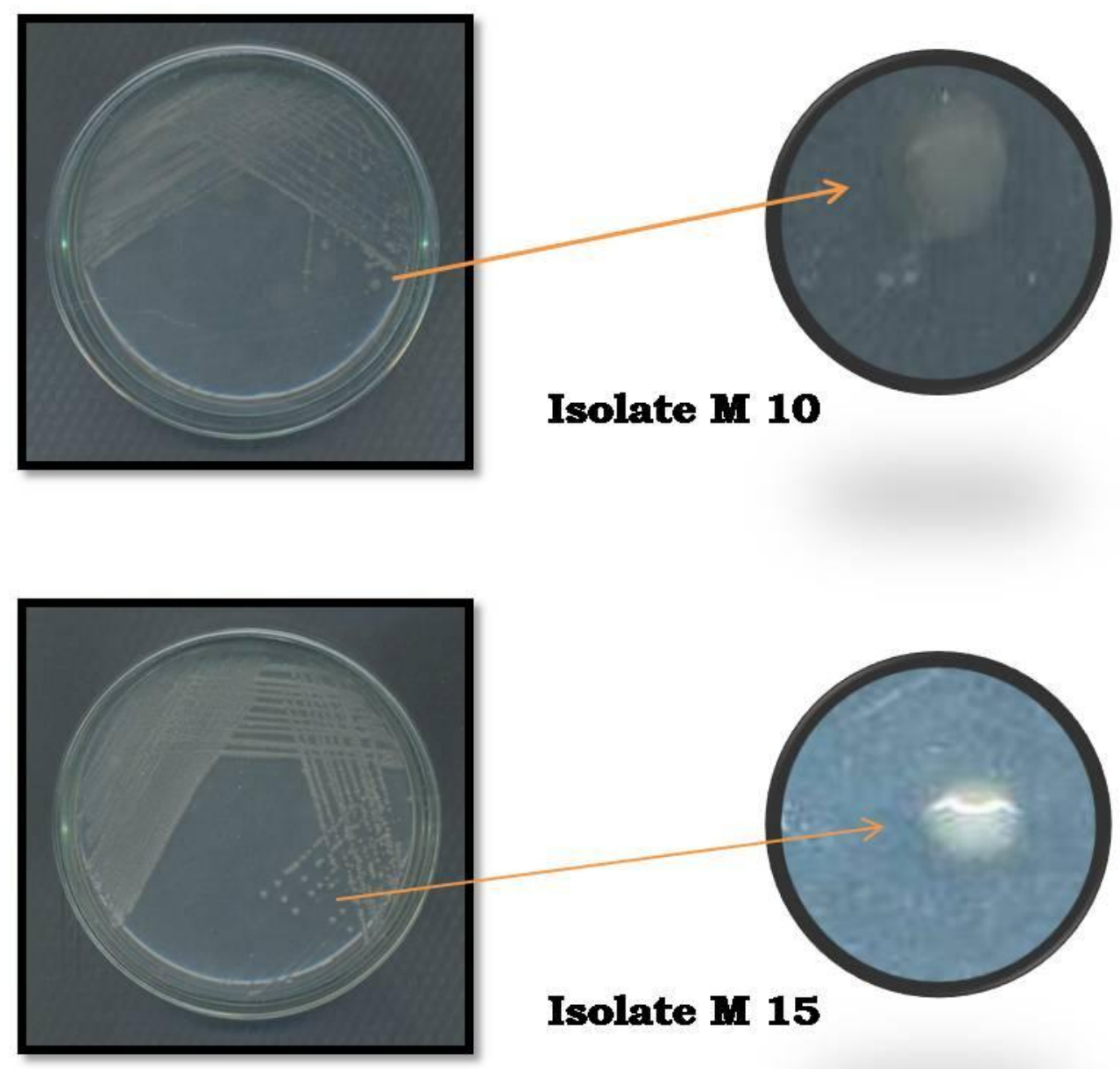

\section{Isolate M 15}

Plate.3 Colony characterization of phyllospheric isolates on NMS medium with $1 \%$ methanol 

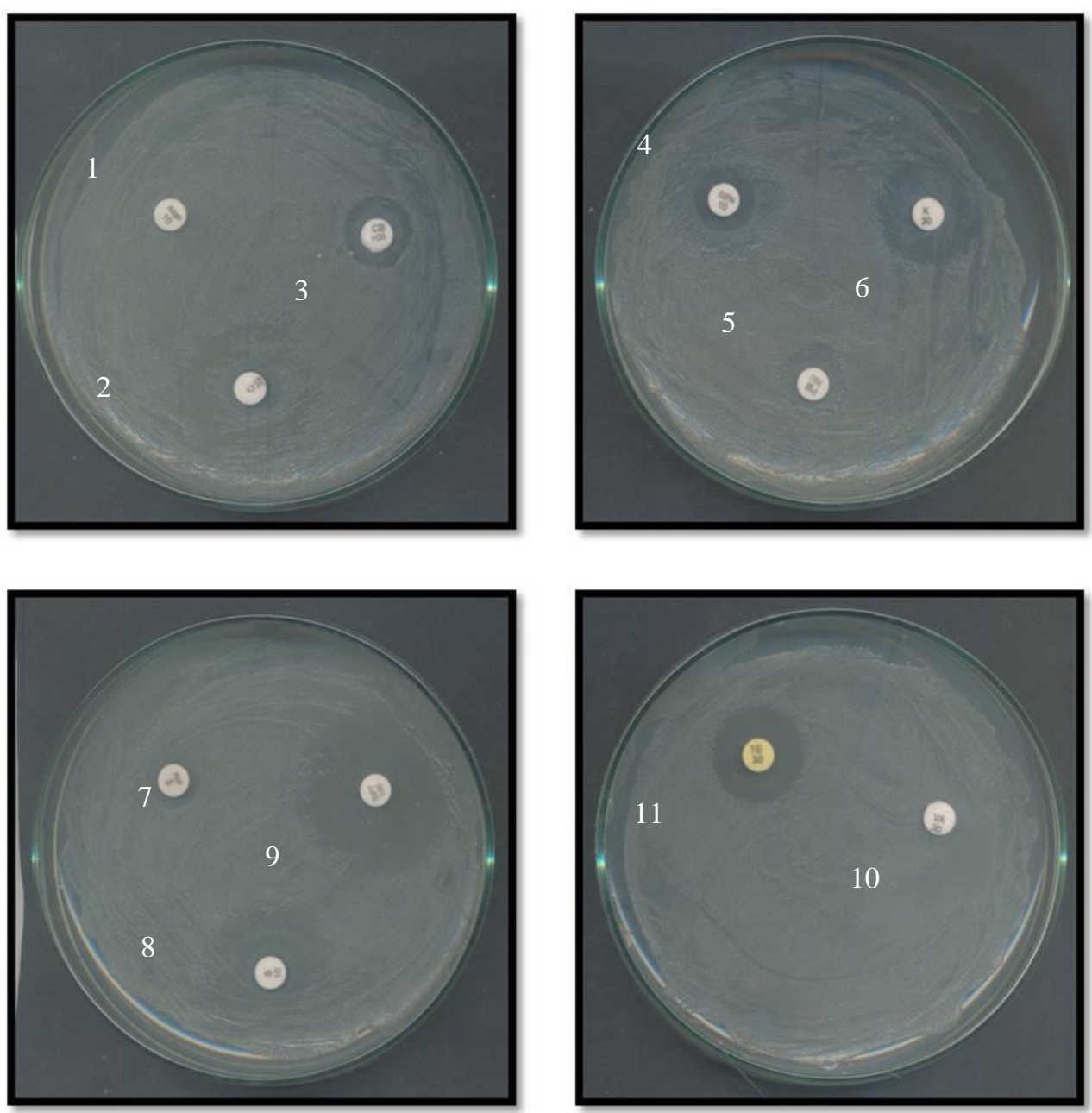

Plate.4 Antibiotics resistance profile of phyllospheric methylotrophic isolate $\mathrm{M}$ 15. 1) AMP- Ampicillin, 2) C-Chloramphenicol, 3) CB- Carbenicillin, 4) GEN- Gentamycin, 5) PB-Polymyxin-B, 6) K- Kanamycin, 7) RIFRifampicin, 8) S- Streptomycin, 9) SPT- Spectinomycin, 10) VAVancomycin, 11) TE- Tetracycline 

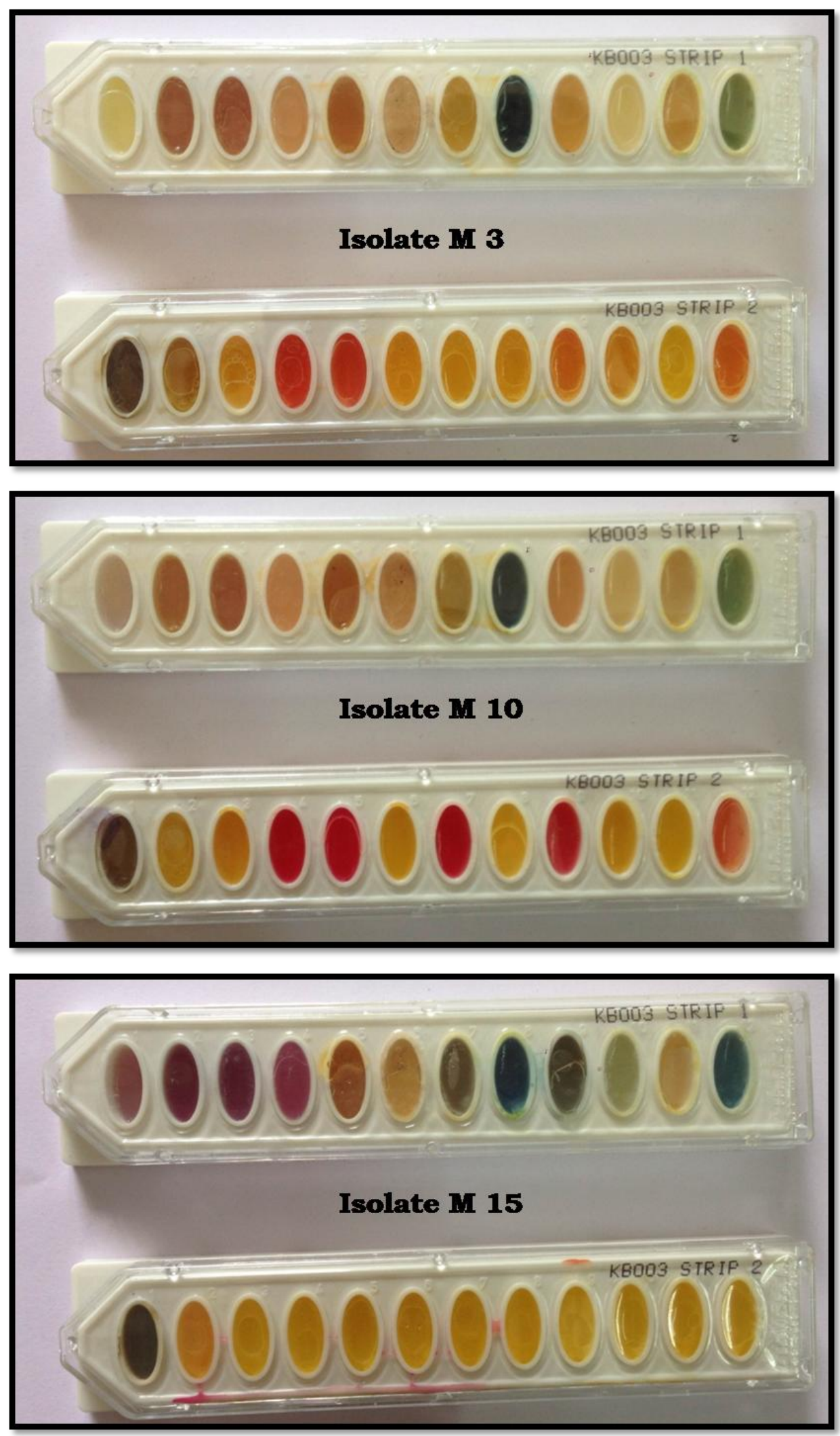

Plate.5 Biochemical characterization of phyllospheric methylotrophic isolates 

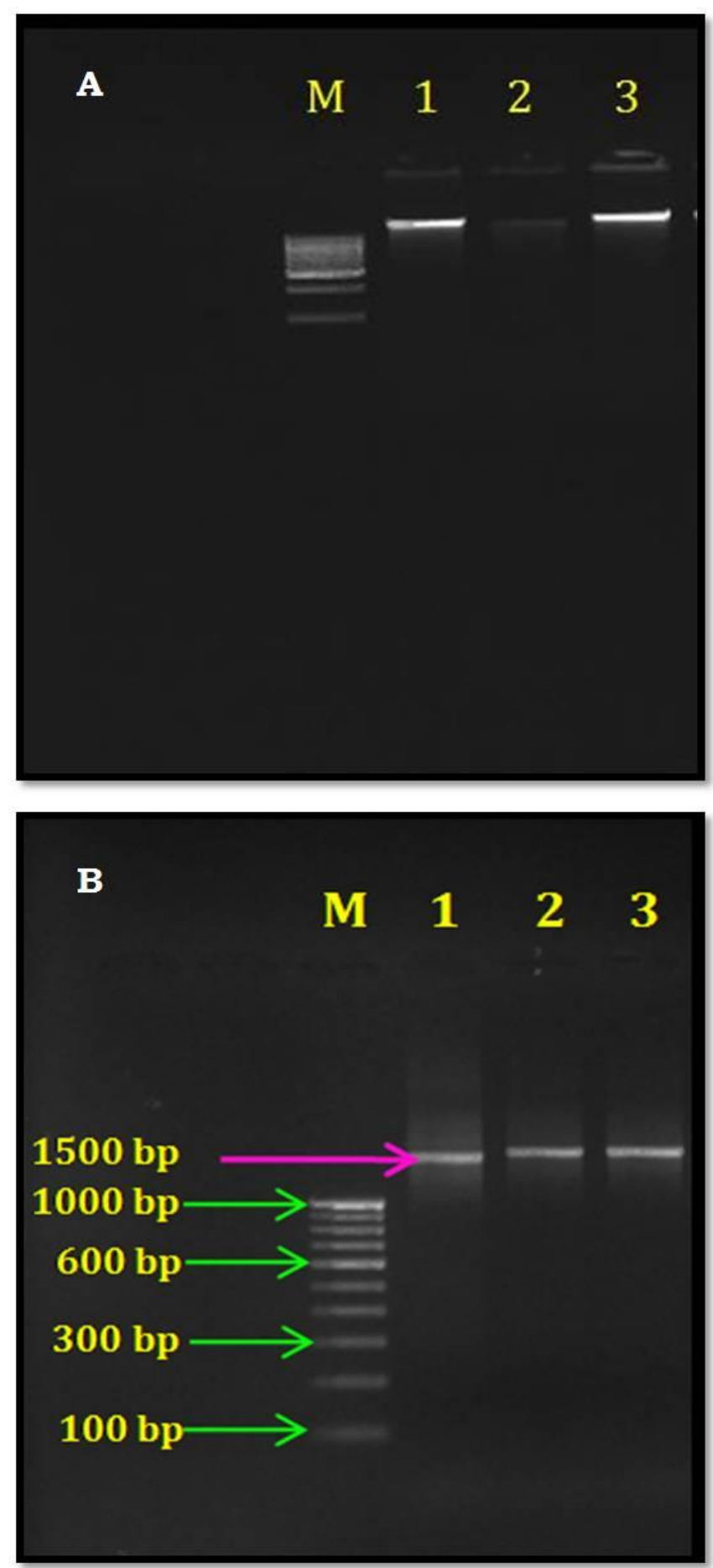

Plate.6 (A) DNA isolation and (B) 16S rRNA gene amplification from phyllospheric methylotrophic isolates. M-Marker, 1- M 3, 2- M 10 and 3- M 15 

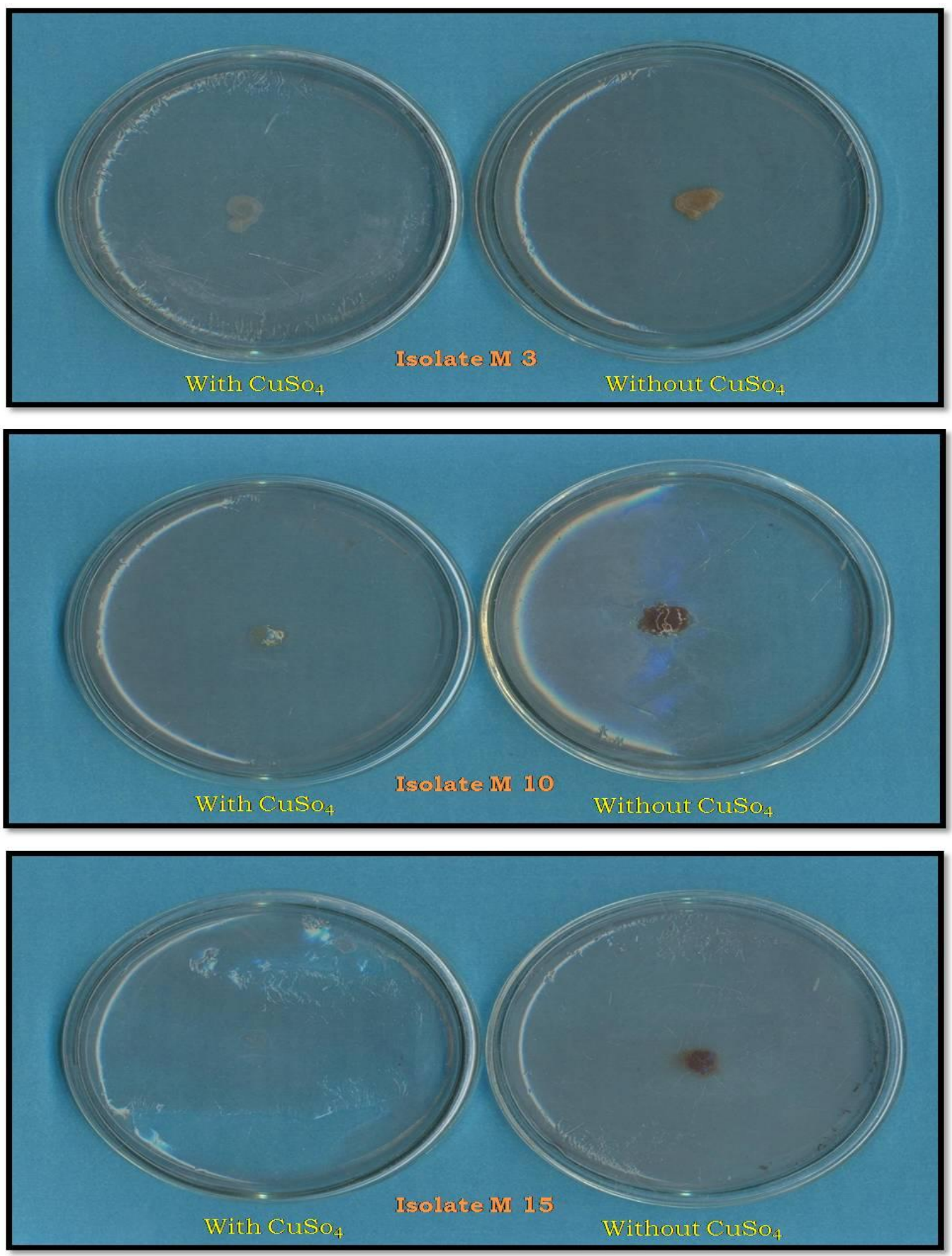

Plate.7 Detection of sMMO activity of isolates in presence and absence of copper on NMS agar 
Figure.1 Phylogenetic tree based on 16S rDNA sequence of phyllospheric methylotrophic isolate M 3

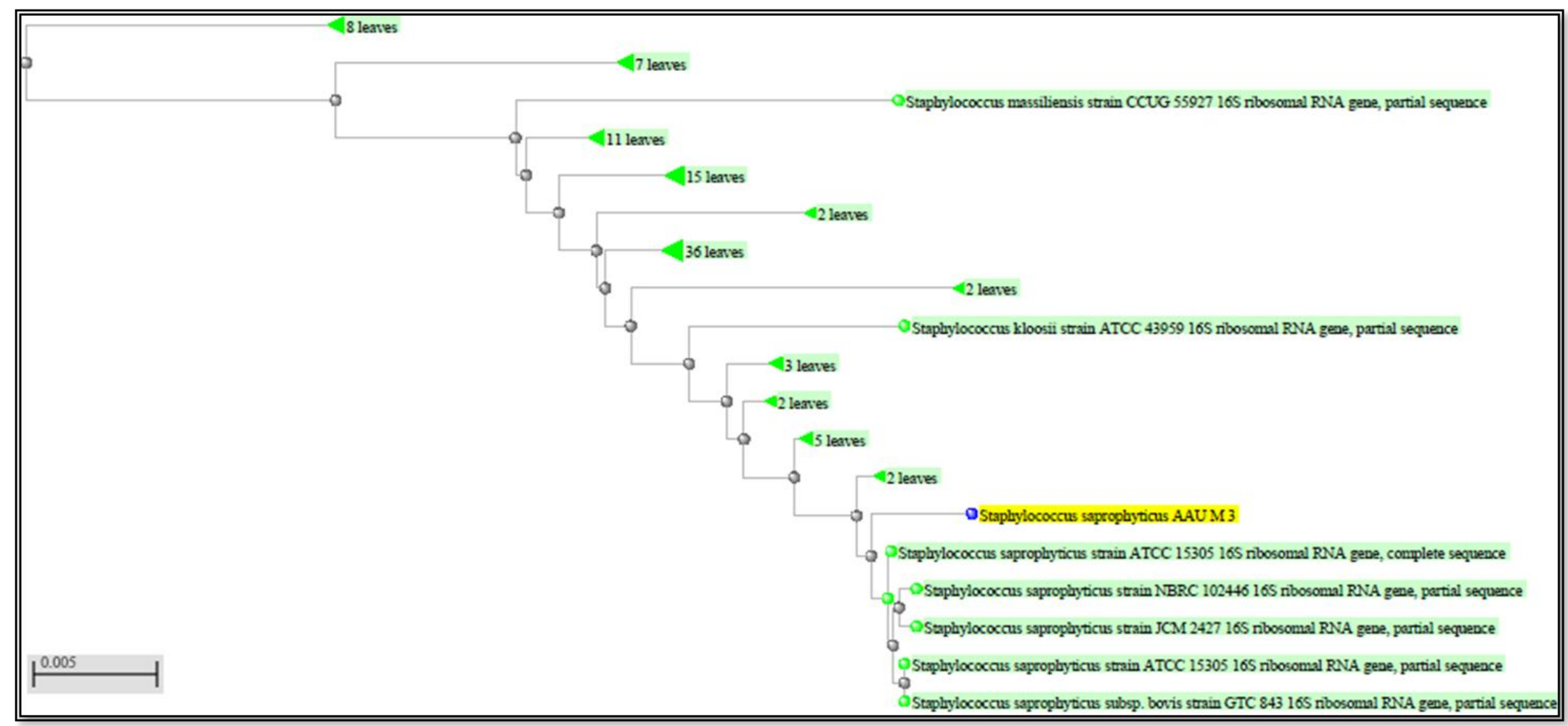


Figure.2 Phylogenetic tree based on $16 \mathrm{~S} r \mathrm{DNA}$ sequence of phyllospheric methylotrophic isolate M 10

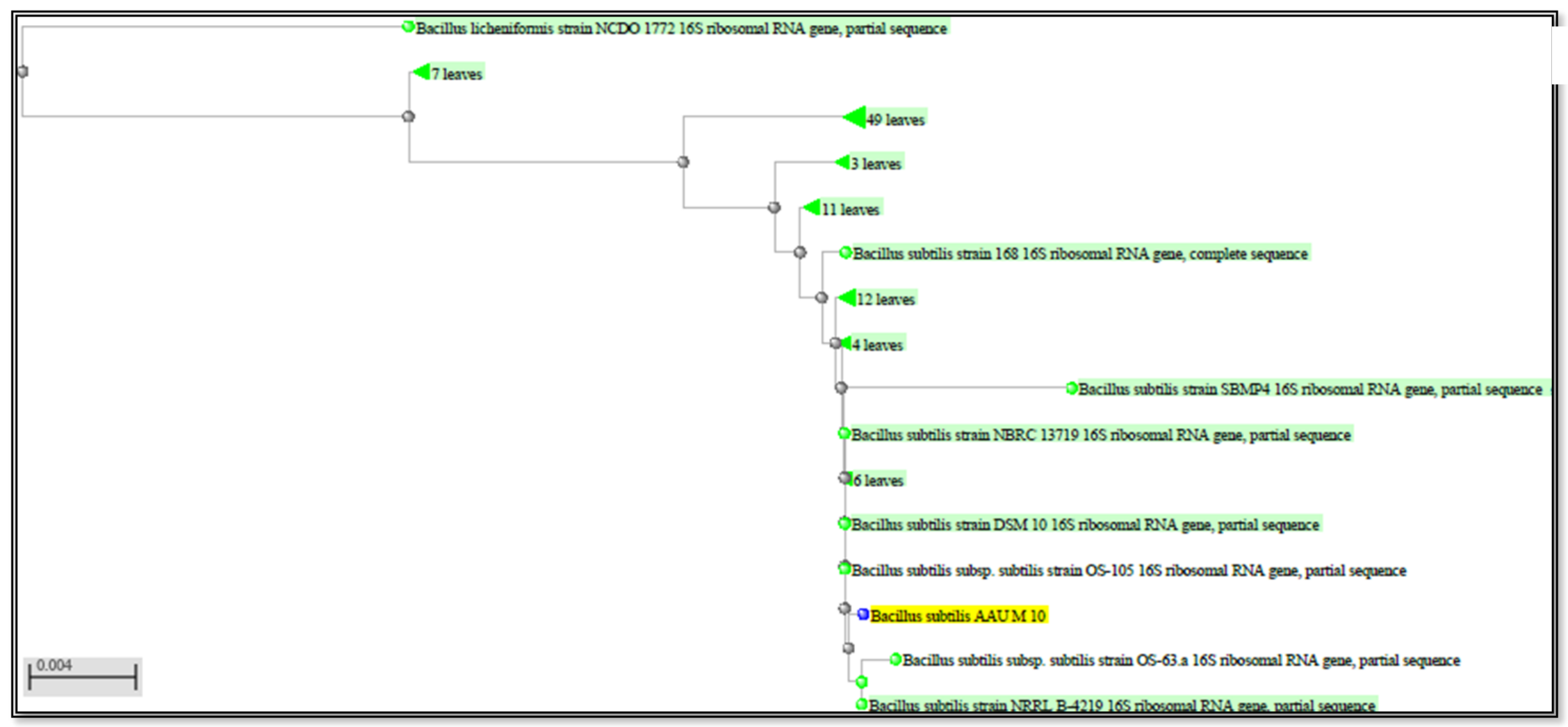


Figure.3 Phylogenetic tree based on 16S rDNA sequence of phyllospheric methylotrophic isolate M 15

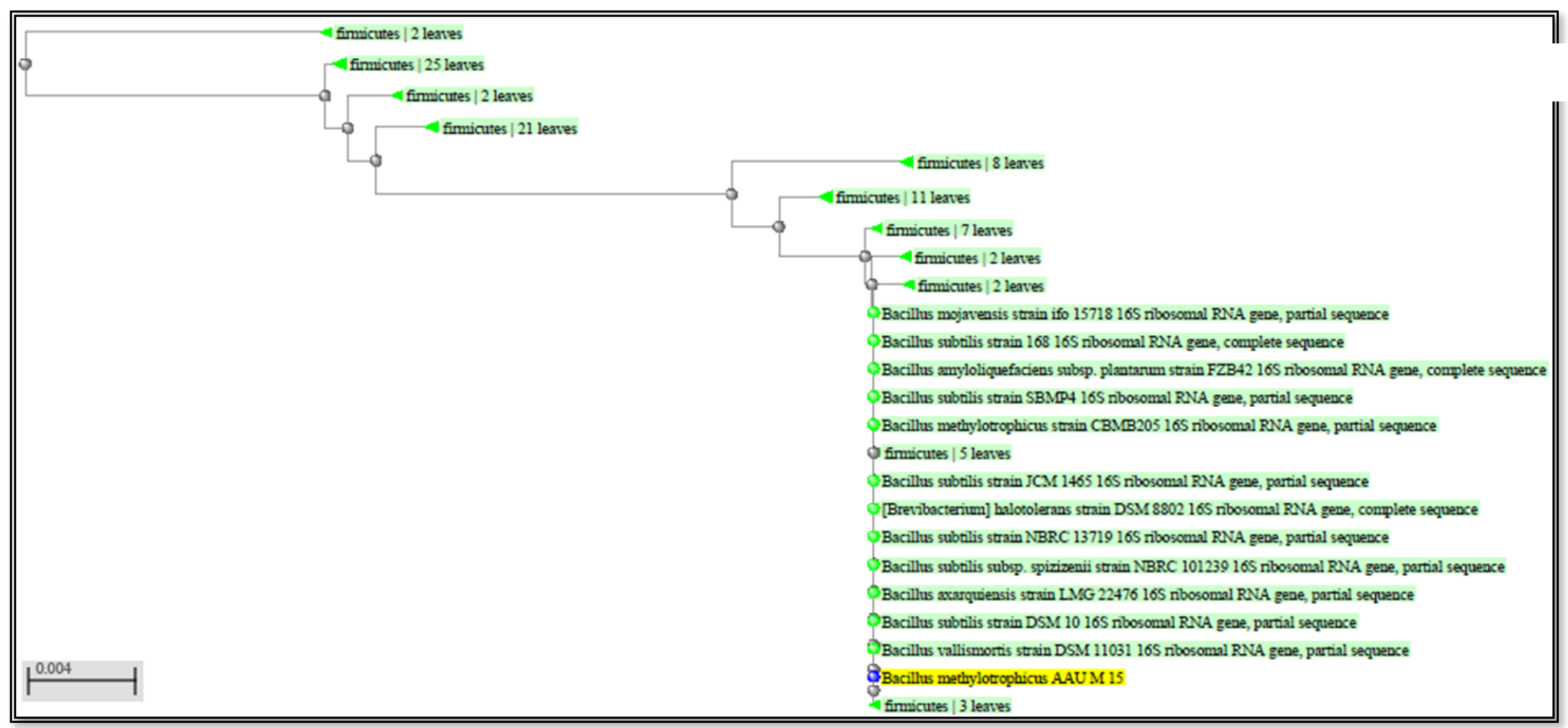


Table.12 Symbols and details

\begin{tabular}{|c|c|}
\hline Symbol & Detail \\
\hline- & No growth \\
\hline+ & Moderate growth \\
\hline
\end{tabular}

Table.13 Identification of methylotrophic isolates by 16S rRNA sequencing

\begin{tabular}{|c|c|c|c|c|c|}
\hline \multirow{2}{*}{ Isolates } & $\begin{array}{c}\text { Length } \\
\text { of 16S rRNA gene } \\
\text { sequenced }\end{array}$ & Species & $\begin{array}{c}\text { Accession } \\
\text { description }\end{array}$ & $\begin{array}{c}\text { Most closely related organism } \\
\text { gene } \\
\text { identity }\end{array}$ & $\begin{array}{c}\text { \% } \\
\text { Query } \\
\text { coverage }\end{array}$ \\
\cline { 3 - 6 } M-3 & 2564 & $\begin{array}{c}\text { Staphylococcus } \\
\text { saprophyticus strain } \\
\text { ATCC 15305 }\end{array}$ & NR_074999.1 & $99 \%$ & $100 \%$ \\
\hline M-10 & 2569 & $\begin{array}{c}\text { Bacillus subtilis subsp. } \\
\text { spizizenii strain } \\
\text { ATCC 6633 }\end{array}$ & NR_118486.1 & $99 \%$ & $99 \%$ \\
\hline M-15 & 1483 & $\begin{array}{c}\text { Bacillus } \\
\text { methylotrophicus } \\
\text { strain CBMB205 }\end{array}$ & NR_116240.1 & $99 \%$ & $100 \%$ \\
\hline
\end{tabular}

* Data obtained after BLAST analysis from NCBI database

Table.14 Soluble methane monooxygenase activity

\begin{tabular}{|l|c|}
\hline \multicolumn{1}{|c|}{ Isolates } & Specific activity \\
\hline S. saprophyticus & + Detected \\
\hline B. subtilis & + Detected \\
\hline B. methylotrophicus & + Detected \\
\hline
\end{tabular}

Note: + Positive detection

Table.15 Methanol dehydrogenase activity

\begin{tabular}{|l|c|}
\hline \multicolumn{1}{|c|}{ Isolates } & Specific activity \\
\hline S. saprophyticus & + Detected \\
\hline B. subtilis & + Detected \\
\hline B. methylotrophicus & + Detected \\
\hline
\end{tabular}

Note: + Positive detection

\section{Biochemical characterization}

Biochemical characterization of selected phyllospheric methylotrophic bacterial isolates were tested for specific breakdown products represented in Table.9, Plate.5.
All chosen methylotrophic bacterial isolates were found positive for malonate utilization. Isolate M 3 was found positive for ONPG, Lysine utilization, Ornithine utilization, citrate utilization and Voges Proskauer's test Isolate M 10 was found positive for citrate utilization and Voges Proskauer's, where as 
Lysine utilization, Ornithine utilization, urease, H2S production, indole were found positive for isolate $\mathrm{M} 15$.

All chosen methylotrophic bacterial isolates were found positive (carbon source utilized) for esculine hydrolysis, arabinose, xylose, sachharose and glucose. Isolate M 15 was found positive for all test. Isolate M 3 was positive for cellobiose whereas, isolate M 10 was positive for rhamnose, melibiose and raffinose Table.10 and Plate.5. Urakami and Komagata (1984) reported that some strains of methylotrophic bacteria can also utilize Larabinose, D-xylose, D-fucose, D-glucose, D-galactose, D-fructose, L-Aspartate, Lglutamate, adipate, Sebacate, D-tartarate, citrate, saccharte, mono-methylamine, trimethylamine, trimethylamine $\mathrm{N}$-oxide, ethanolamine, butylamine, dimethylglycine and betaine, ammonia, nitrate and urea as source of nitrogen.

\section{Utilization of other $\mathrm{C} 1$ compounds}

All the isolates showed good growth on $1 \%$ formaldehyde which is the third product of methane metabolism, after methane gas and methanol which were conformed in previous aspects. Isolate M 3, M 10 and M 15 were found to utilize $1 \%$ concentration of trichloroethylene, whereas, isolate M 15 showed good growth in trichloroethylene and methyl acetate at $2 \%$ concentration (Table.11).

These results indicate the presence of methane mono oxygenase enzyme in isolates which is required for oxidation of trichloroethylene like $\mathrm{C} 1$ compounds. Aken et al.,(2011) reported that M. populi sp. nov., a novel aerobic, pink-pigmented, facultative methylotrophic, methane-utilizing bacterium isolated from poplar trees was able to utilize fructose, acetate, betadine, tartrate, ethanol, methane and methylamine as carbon sources.

\section{Molecular characterization}

\section{S rRNA gene amplification}

PCR amplification of 16S rRNA gene from selected three phyllospheric methylotrophic bacterial isolates were carried out using universal primers (U27f and U1492r). These primers gave single band of 1500 bp on $2 \%$ agarose gel. All the isolates successfully gave amplification of such band (Plate.6).

\section{DNA sequencing and identification}

16S rRNA partial gene sequence of $~ 1500 \mathrm{bp}$ was carried out (with technical support of Chromus Biotech, Mumbai) and the output data were stored in FASTA format. The output sequences were subjected for BLAST (Basic Local Alignment Search Tool) analysis to identify the cultures and to find out the nearest match of the cultures (http://www.ncbi.nlm.nih.gov/). Isolate M 3 was identified as S. saprophyticus with $99 \%$ similarity and $100 \%$ query coverage to $\mathrm{S}$. saprophyticus strain ATCC 15305 (Table.13). Additionally, the phylogenetic position of the isolate was also worked out within the available database of NCBI (presented as phylogenetic tree in Figure.1). Isolate M 10 was identified as B. subtilis showing $99 \%$ identity with $B$. subtilis sub sp. spizizenii strain ATCC 6633 with $99 \%$ query coverage (Table.13) which confirms the isolate M 10 belongs to Bacillus genus (Figure.2). Isolate M 15 was also identified as $B$. methylotrophicus with $99 \%$ similarity and $100 \%$ query coverage to B. methylotrophicus strain CBMB205 (Table.13). The phylogenetic tree constructed showed one major clusters showing close similarity with B. methylotrophicus and B. subtilis (Figure.3). Madhaiyan et al.,(2012) employed comparative 16S rRNA gene sequence-based phylogenetic analysis to identify a novel plant-associated obligate methylotrophic 
bacterium from the rhizospheric soil of fieldgrown red pepper from India and designated strain as M. rhizosphaerae sp. nov.Ca-68T.

\section{In vitro enzyme activities for methane degradation}

\section{Methane monooxygenase activity}

Qualitative detection of soluble methane monooxygenase (sMMO) activity data are presented in Table.14. Selected methanotrophic colonies expressing sMMO turned deep purple, when exposed successively to naphthalene and o-dianisidine.

Isolate M 3, M 10 and $M 15$ were found positive for sMMO activity in absence of copper ions in media. Moreover, when media was supplemented with $\mathrm{CuSO} 4$, sMMO activity was not detected (Plate.7). Similar results were obtained by Koh et al.,(1993) while working with the methylotrophic strain M. methanica 68-1 which showed soluble methane monooxygenase activity in the absence of copper ions in media.

\section{Methanol dehydrogenase assay}

All selected isolates were found positive for methanol dehydrogenase activity (Table.15). These results confirms the outcome of previous experiment, wherein B. subtilis and B. methylotrophicus were showed better survival at 1 to $5 \%$ methanol concentrations may be due to higher rate of methanol dehydrogenase activity.

Arfman et al., (1989) reported that cell free extract of Bacillus sp. $\mathrm{C} 1$ were found to possess NAD dependent methanol dehydrogenase activities ranging from 1,000$1,200 \mathrm{nmol}$ min- $1 \mathrm{mg}-1$ of protein and also reported that carbon assimilation was by way of RuMP cycle of formaldehyde fixation.

\section{Acknowledgements}

We wish to thank Dr. G. B. Patil (Assistant professor) and Dr. Arpan Modi (Research Asso.) Centre for Advanced Research in Plant Tissue Culture, Department of Agril. Biotechnology, Anand Agricultural University, Anand, Gujarat, India for their help in molecular work and advice regarding the paper writing.

\section{References}

Aken, B., Tehrani, R. and Schnoor, J.L. 2011. Endophyte-assisted phytoremediation of explosives in poplar trees by Methylobacterium populi BJ001T. For. Sci., 80: 217-234.

Anthony, C. 1982. The Biochemistry of Methylotrophs. Academic Press, London.

Arfman, N., Watling, E.M., Clement, W., Van Oosterwijk, R.J., de Vries, G.E., Harder, T.W., Attwood, M.M. and Dijkhuizen, L. 1989. Methanol metabolism in thermotolerant methylotrophic Bacillus strains involving a novel catabolic NADdependent methanol dehydrogenase as a key enzyme. Arch. Microbiol., 152: 280288.

Bergey, D.H., Breed, R.S., Murray, E.G.D. and Hitchens, A.P. 1939. Bacterium methylicum (Loew. Migula. Bacillus methylicus Loew. In Bergey's Manual of Determinative Bacteriology. Bergey, D.H., Breed, R.S., Murray, E.G.D., and Hitchens, A.P. eds. London: Baillière, Tindall \& Cox. 5th ed., p. 597.

Corpe, W.A. 1985. A method for detecting methylotrophic bacteria on solid-surfaces. J. Microbiol. Meth. 3(3-4): 215-221.

Eggeling, L. and Sahm, H. 1980. Direct enzymatic assay for alcohol oxidase, alcohol dehydrogenase and formaldehyde dehydrogenase in colonies of Hansenula polymorpha. Appl. Environ. Microbiol., 39(1): 268-269.

Graham, D.W., Korich, D.G., Leblanc, R.P. Sinclair, N.A. and. Arnold, R.G. 1992. Applications of a colorimetric plate assay for soluble methane monooxygenase 
activity. Appl. Environ. Microbiol., 58(7): 2231-2236.

Jhala, Y.K., Vyas, R.V., Panpatte, D.G. and Shelat H.N. 2015. Rapid Methods for Isolation and Screening of Methane Degrading Bacteria. J. Bioremed. Biodeg., 7(1): 1-5.

Kim, K.Y., Madhaiyan, M., Yim, W.J., Chauhan, P.S. and Sa, T.M. 2010. A novel pink pigmented facultative methylobacterium phyllosphaerae sp. Nov. from phyllosphere of rice. World congress of soil science, soil solution for a changing world.

Knief, C., Dengler, V., Bodelier, P.L.E. and Vorholt, J.A. 2010. Characterization of Methylobacterium strains isolated from the phyllosphere and description of Methylobacterium longum sp. nov. Antonie van Leeuwenhoek, 101:169-183.

Koh, S., Bowman, J.P. and Sayler, G.S. 1993. Soluble methane monooxygenase production and trichloroethylene degradation by a type I methanotroph, methylomonas methanica 68-1. Appl. and Environ. Microbial., 59(4): 960-967.
Madhaiyan, M., Poonguzhali, S., Senthilkumar, M., Pragatheswari, D., Lee, K.C. and Lee, J.S. 2012. Methylobacillus rhizosphaerae sp. nov., a novel plant-associated methylotrophic bacterium isolated from rhizosphere of red pepper. Antonie van Leeuwenhoek, 32: 212-214.

Omer, Z.S., Tombolini, R. and Gerhardson, B. 2004. Plant colonization by pink pigmented facultative methylotrophic bacteria. FEMS Microbiol. Ecol., 47: 319-326.

Sambrook, J., Fritsch, E.F. and Maniatis, T. 1989. Molecular cloning: a laboratory manual, 2nd Ed. Cold Spring Harbor Laboratory, Cold Spring Harbor, N.Y.

Urakami, T. and Komagata, K. 1987. Characterization of Species of Marine Methylotrophs of the Genus Me thy lop haga. Inter. J. Syst. Bacteriol., 37(4): 402406.

Weisburg, W.G., Barns, S.M., Pelletier, D.A. and Lane, D.J. 1991. 16S ribosomal DNA amplification for phylogenetic study. $J$. Bacteriol., 173(2): 697-703.

\section{How to cite this article:}

Ronak R. Prajapati, R.V. Vyas and Jhala, Y.K. 2017. Isolation and Characterization of Phyllospheric Methylotrophic Bacteria of Paddy from Middle Gujarat. Int.J.Curr.Microbiol.App.Sci. 6(5): 2186-2208. doi: https://doi.org/10.20546/ijcmas.2017.605.246 